\title{
PREVALENCE OF THE HYPOTHYROIDISIM AMONG YOUNG ADULTS IN HYDERABAD
}

KEY WORD:

\author{
Mrs.Rama.V * \\ Mrs. A.Jyothi
}

(Ph.D Scholar).*Corresponding Author

(Professor), Sri Padmavathi Mahila Viswa Vidhyalayam, Tirupati, Andhra Pradesh, India.

\section{OBJECTIVES:}

- To identify the severity of hypothyroidism among young adults in Hyderabad.

- To determine the association between selected variables and hypothyroidism.

- To select the subjects for the main study

\section{MATERIALS AND METHODS:}

Study was descriptive in nature. Data was conducted in selected paramedical and engineering colleges of Hyderabad, Telangana, India. The sample consists of 500 young adults. The sample was selected by simple random sampling technique.Data was collected by using self-administering structured questionnaire.

FINDINGS: $0.6 \%$ of subjects were suffering from hyperthyroidism, $2 \%$ of subjects are suffering from hypothyroidism, and $14.6 \%$ are suffering from Subclinical hypothyroidism. $75 \%$ of subjects where females $.95 \%$ subjects belong to Hindu religion. $95 \%$ parents of subjects were educated. $90 \%$ of the subject aged 21 years, $50 \%$ subjects are showing average performance. $25 \%$ parents of the subjects were suffering from thyroid disorders $90 \%$ of them are mothers. $20 \%$ of the subjects are suffering of any one kind of health problems, $70 \%$ of the females are suffering from menstrual disturbance. $80 \%$ of subjects are having overview about the thyroid disorders. $2 \%$ of the subjects are suffering from palpitations. $20 \%$ of subjects having poor concentration. $5 \%$ are suffering from memory loss. $25 \%$ are suffering from excessive need for excess sleep. $10 \%$ are suffering from depression. $60 \%$ complained unusual hair loss. $20 \%$ are having unusual weight gain. These are the major findings of the study.

CONCLUSION: Majority of the subjects were unable to identify their symptoms of hypothyroidism.25\% of the subjects are with symptoms of hypothyroidism. Awareness about periodical screening for thyroid disorders need to be improved among public through health education.

\section{INTRODUCTION}

Among thyroid disorders, Hypothyroidism is the most common type of endocrine disorder, in which the thyroid gland produces fewer amounts of thyroid hormone. Thyroid disorders are different from other disorders in terms of their unspecific symptoms, diagnosis, accessibility of medical treatment. If subclinical thyroid disorders are not diagnosed as early as possible, progresses to overt thyroid disorders. Signs and symptoms of hypothyroidism are poor memory, excessive sleepiness, lethargy, depression, menstrual disturbances, decreased skin integrity, feeling cold, abnormal hair loss, decreased cardiac output, weight gain, constipation etc.

Iodine is the major cofactor and stimulation for thyroid peroxide (TPO). Iodine deficiency leads to impaired functioning of the thyroid gland that results in hypothyroidism or subclinical hypothyroidism. According to the published research findings, 3-8 percent of the world's population have subclinical hypothyroidism among them 26.8 percent developed full-blown hypothyroidism within six years of their initial diagnosis. As per the study done by Ambika et.al (2011), on the epidemiological perspective of thyroid disorders in India, thyroid disorders are one of the most common endocrine disorders, 42 million people in India suffer from thyroid disorders.

In the present study, the researcher wanted to determine the present scenario related to Prevalence of the hypothyroidism among young adults, with the gained information to plan the main study and to develop nutritional supplement for patients with Subclinical hypothyroidism accordingly.

\section{OBJECTIVES OF THE STUDY:}

1) To identify the severity of Hypothyroidism among young adults.

2) To determine the association between selected variables and hypothyroidism among young adults.

3) To select the subjects for the main study.

\section{OPERATIONAL DEFINITIONS}

Prevalence: The number of cases with a specific disease, existing at a particular time within a given population.

Hypothyroidism: Type of endocrine disorder, in which thyroid gland produces fewer amounts of thyroid hormone. Young adults: Individuals aged between 19-24 Years.

\section{ASSUIMPTIONS}

- It is assumed that among women prevalence of hypothyroidism is high.

- Most of the people with hypothyroidism are in the SubClinical stage.

- Majority of the women with hypothyroidism are suffering from reproductive problems.

\section{DELIMITATIONS:}

- Study was confined to young adults of Hyderabad.

- Study was limited to young adults available at the time of data collection.

- Study was delimited to selected age group.

\section{HYPOTHESIS}

There will be a statistically significant association between selected variables and the Prevalence of hypothyroidism among young adults.

\section{NULL HYPOTHESIS}

There will be no significant association between selected variables and the Prevalence of hypothyroidism among young adults.

Known causes of hypothyroidism are low dietary intake of iodine, inactive thyroid gland, pituitary gland disorders, autoimmune diseases, and thyroid infection. Iodine deficiency is one of the most prevalent causes of impaired thyroid function and goitre. Iodine compounds are mainly found in seawater and soil. Plants grown in these soils yield vegetable fruits and other products with a good amount of iodine. Cattle eating these plants also produce milk with better iodine content. Seafood always has rich sources of 
iodine. In certain mountainous parts of the world such as the Andes, the Himalayas, and Central Africa, there is a dietary deficiency of iodine and many people in these areas have an endemic goitre.

The introduction of dietary iodine fortification with table salt for the prevention of IDD was started in 1922 in Switzerland. But it took nearly 70 years for the universal salt iodization. In 1993, WHO and UNICEF recommended Universal salt iodization (USI) as the main strategy to achieve the elimination of IDD. By, 2002, more than 1170 countries had committed themselves to USI and 691 of the world population are using adequate iodized salt. After implementation of USI, the report of the National Rural Health Mission (NRHM) of India in 2006 has revealed that the sample surveys conducted in 324 districts identified that 263 are endemic for iodine deficiency. Given this information, the researcher wanted to determine, at present how much is the prevalence of hypothyroidism in the state of Telangana.

\section{MATERIALS AND METHODS}

The following methods were used to complete this study.

\section{RESEARCH APPROACH}

Non-Experimental Approach

\section{RESEARCH DESIGN}

Descriptive survey design

\section{SETTING FOR THE STUDY}

Selected medical and engineering colleges in Hyderabad, Telangana State, India.

\section{POPULATION}

Young adults of age between 20-24 Years

\section{SAMPLING TECHNIQUE:}

A simple random sampling technique (lottery method) was used to collect the desired sample. In two steps sampling was done.

1. In the first step selection of colleges was done, five engineering colleges, three pharmacy colleges, and two nursing colleges were picked through the lottery method.

2. the Desired sample was selected from the selected ten colleges, through simple random sampling.

\section{SAIMPLE}

The sample consists of 500 young adults studying in different educational institutions of Hyderabad, Telangana.

\section{METHOD OF DATA COLLECTION}

Data were collected in two phases. After taking permission from the college administrations, started collecting data from the students. A list of the students was obtained from each college then, by lottery method chosen the desired sample of 500 members. Informed consent was taken from the students.

1. In the first phase collected detailed information about demographic data, personal history, family history and the symptomatic assessment was done.

2. In the second phase blood test was performed, to determine thyroid-stimulating hormone levels, of the subjects.

\section{TOOLS FOR DATA COLLECTION}

Data was collected by using a structured self-administering questionnaire (SAQ) about signs and symptoms of hypothyroidism and by performing biochemical analysis of the blood to determine thyroid-stimulating hormone levels. Related literature was reviewed and discussed with experts in the fields of endocrinology and nutrition for developing appropriate and suitable tool. The tool was divided into the three sections like demographic data, symptomatic assessment, and Biochemical analysis for Thyroid hormones levels (blood test)

\section{INTERPRETATION OF THYROID TEST AS PER AMERICANTHYROID ASSOCIATION}

\section{Test Name}

T3(Triiodothyronine)

T4 (Total Thyroxine)

TSH (Thyroid Stimulating Hormone)

\section{Reference range}

$60-200 \mathrm{ng} / \mathrm{dl}$

$4.5-12 \mu \mathrm{g} / \mathrm{dl}$

$0.30-5.5 \mu \mathrm{IU} / \mathrm{ml}$
(Test method: Competitive Chemical Immune Assay)

- Hypothyroidism:if T4 $<12 \mu \mathrm{g} / \mathrm{dl}$ $\mathrm{TSH}>5.5 \mu \mathrm{IU} / \mathrm{ml}$

- Sub Clinical Hypothyroidism: Positive Hypothyroid symptoms with blood TSH levels more than the lower limit $(>0.30 \mu \mathrm{IU} / \mathrm{ml})$

- Hyperthyroidism: if T4 $>12 \mathrm{ug} / \mathrm{dl}$ and TSH $<0.30 \mu \mathrm{IU} / \mathrm{ml}$

- Subclinical hyperthyroidism: positive Hyperthyroid symptoms with blood TSH levels less than the lower limit $(<0.30 \mu \mathrm{IU} / \mathrm{ml})$

\section{RESULTS}

This study is aimed at gathering information about the prevalence of hypothyroidism among young adults. 500 young adults were screened during the study. statistical evidence is presented in the form of tables.

\section{The major findings of the study are as follows:}

1) Demographic findings:

- More than half of the members were females (75\%).

- $340(68 \%)$ subjects are studying Engineering, 99 (19.8\%) pharmacy and 61 (12.2\%) studying B.Sc. nursing

- Subjects with the age of 20 years occupies 73.4 percent of the sample among them more than half (262 members) were studying engineering, which was found to be a statically significant association(chi-square test, pvalue:0.00) (Table:1)

- Highest percentage (95\%) of the subjects belonged to the Hindu religion.

- Only five percent of the subjects parents were uneducated.

- Half of the subjects (50\%) are having average academic performance, twenty-five percent are having aboveaverage academic performance and the remaining twenty-five percent are having below-average performance.

- Eighty-two percent of the subjects are having an overview of thyroid disorders. Fourth eight percent of subjects know through their teachers, $13.6 \%$ through newspapers, $9.2 \%$ from T.V and the internet and $11.2 \%$ percent from parents.

- Eight (1.6\%) subjects are suffering from Hypothyroidism among them five members are studying engineering, which was not found to be a statically significant association(chi-square test, p-value: 0.510) (Table no:2). Among the seven (1.4\%) are under medication.

- 12.2 percent of subjects are having health problems other than thyroid disorders. Among them 6.2 percent are having systemic problems, $5.6 \%$ are having general problems, 0.2 percent are having reproductive problems and 0.2 percent are having congenital malformations.

- Nearly one-fourth of parents $(20.2 \%)$ of the subjects were suffering from thyroid disorders among them $70 \%$ were studying engineering, which was not found to be a statistically significant association (chi-square test, pvalue 0.848 ) (Table no:3). Among the parents $90 \%$ were mothers.

- 20 percent of subjects are vegetarians, $11.8 \%$ non vegetarians and $68 \%$ are eating occasionally Nonvegetarian food.

- Majority of the subjects (94.8\%) are consuming iodized salt.

Symptomatic assessment: 
- 32.2 percent of the subjects are weighing more than 55 kilogrammes.

- 15 percent of subjects are having eye pain and sight.

- Thirty-three $(6.6 \%)$ subjects are complaining about swelling in the neck among them 24 were studying engineering, which was not found to be statistically significant (chi-square test, p-value: 0.234 ) (Table no:4)

- Twenty (4\%) subjects were having a sensation of a lump in the throat and difficulty in swallowing, among them 14 were studying engineering, which was not found to be a statistically significant association. (chi-square test, pvalue:0.554) (Table no:5)

- 10.6 percent of the subjects are expressing weakness of muscles.

- 19.8 percent of subjects are suffering from easy fatigue.

- Two percent of the subjects are suffering from palpitations.

- 27.2 percent of subjects are having poor concentration.

- Five percent of subjects are suffering from memory loss.

- One fourth percentage (25\%) are suffering from the excessive need for sleep.

- Ten percent of subjects are suffering from depression.

- More than half (50.4\%) subjects are having unusual hair loss and $37.4 \%$ are suffering from dryness of hair.

- Twenty percent of the subjects are suffering from easy weight gain.

- 16 percent of subjects are unable to tolerate the cold.

- 4.4 percent of female young adults are having problem with excessive menstrual flow and 38 (7.6\%) members are suffering from irregular periods among them 21 members were studying engineering, which was not found to be a statistically significant association (chisquare test, $p$-value:0.24)(Table no:6)

\section{Thyroid hormone test results:}

Among 500 young adults, 14.6 percent were reported with Subclinical hypothyroidism, 2 percent with Hypothyroidism and 0.6 percent with Hyperthyroidism, among them majority are females, which was found to be a statistically significant association (chi-square test, p-value:0.00)(Table no:7)

Table no: 1Distribution of the subjects as per type of Course studying and Age

\begin{tabular}{|c|c|c|c|c|c|c|c|}
\hline \multicolumn{2}{|l|}{ Course } & \multicolumn{4}{|c|}{ Age } & \multirow[t]{2}{*}{ Total } & \multirow[t]{2}{*}{ P-Value } \\
\hline & & $\begin{array}{c}20 \\
\text { Years }\end{array}$ & $\begin{array}{c}21 \\
\text { Years }\end{array}$ & \begin{tabular}{|c|}
22 \\
Years
\end{tabular} & \begin{tabular}{|c|}
24 \\
Years \\
\end{tabular} & & \\
\hline \multirow{2}{*}{ Engineering } & $\mathrm{N}$ & 262 & 58 & 19 & 1 & 340 & \multirow[t]{8}{*}{0.00} \\
\hline & $\%$ & $77.1 \%$ & $17.1 \%$ & $5.6 \%$ & $0.3 \%$ & $100.0 \%$ & \\
\hline \multirow[t]{2}{*}{ Nursing } & $\mathrm{N}$ & 33 & 14 & 11 & 3 & 61 & \\
\hline & $\%$ & $54.1 \%$ & $23.0 \%$ & $18.0 \%$ & $4.9 \%$ & $100.0 \%$ & \\
\hline \multirow[t]{2}{*}{ Pharmacy } & $\mathrm{N}$ & 72 & 15 & 12 & 0 & 99 & \\
\hline & $\%$ & $72.7 \%$ & $15.2 \%$ & $12.1 \%$ & $0.0 \%$ & $100.0 \%$ & \\
\hline \multirow[t]{2}{*}{ Total } & $\mathrm{N}$ & 367 & 87 & 42 & 4 & 500 & \\
\hline & $\%$ & $73.4 \%$ & $17.4 \%$ & $8.4 \%$ & $0.8 \%$ & $100.0 \%$ & \\
\hline
\end{tabular}

Table no:Distribution of the subjects as per type of Course studying and history of Thyroid disorders

\begin{tabular}{|c|c|c|c|c|c|}
\hline \multicolumn{2}{|c|}{ Course } & \multicolumn{2}{|c|}{$\begin{array}{c}\text { Do you have any history } \\
\text { of Thyroid disorders }\end{array}$} & \multirow{2}{*}{ Total } & \multirow{2}{*}{$\begin{array}{c}\text { P- } \\
\text { Value }\end{array}$} \\
\cline { 3 - 5 } \multicolumn{2}{|c|}{} & No & Yes & & \\
\hline \multirow{2}{*}{ Engineering } & $\mathrm{N}$ & 335 & 5 & 340 & 0.510 \\
& $\%$ & $98.5 \%$ & $1.5 \%$ & $100.0 \%$ & \\
\hline \multirow{2}{*}{ Nursing } & $\mathrm{N}$ & 59 & 2 & 61 \\
\cline { 2 - 5 } & $\%$ & $96.7 \%$ & $3.3 \%$ & $100.0 \%$ \\
\hline \multirow{2}{*}{ Pharmacy } & $\mathrm{N}$ & 98 & 1 & 99 \\
\cline { 2 - 5 } & $\%$ & $99.0 \%$ & $1.0 \%$ & $100.0 \%$ \\
\hline \multirow{2}{*}{ Total } & $\mathrm{N}$ & 492 & 8 & 500 \\
\cline { 2 - 5 } & $\%$ & $98.4 \%$ & $1.6 \%$ & $100.0 \%$ & \\
\hline
\end{tabular}

Table no: 3Distribution of the subjects as per Course studying and their family members suffering from Thyroid disorders

|www.worldwidejournals.com

\begin{tabular}{|c|c|c|c|c|c|}
\hline \multirow{2}{*}{ Course } & \multicolumn{2}{|c|}{$\begin{array}{c}\text { Any of your family } \\
\text { members are suffering from } \\
\text { Thyroid disorders }\end{array}$} & \multirow{2}{*}{ Total } & P- \\
Value & & \\
\cline { 2 - 5 } & & No & Yes & & \\
\hline \multirow{2}{*}{ Engineering } & $\mathrm{N}$ & 270 & 70 & 340 & 0.848 \\
\cline { 2 - 5 } & $\%$ & $79.4 \%$ & $20.6 \%$ & $100.0 \%$ & \\
\hline \multirow{2}{*}{ Nursing } & $\mathrm{N}$ & 48 & 13 & 61 \\
\cline { 2 - 5 } & $\%$ & $78.7 \%$ & $21.3 \%$ & $100.0 \%$ \\
\hline \multirow{2}{*}{ Pharmacy } & $\mathrm{N}$ & 81 & 18 & 99 \\
\cline { 2 - 5 } & $\%$ & $81.8 \%$ & $18.2 \%$ & $100.0 \%$ \\
\hline \multirow{2}{*}{ Total } & $\mathrm{N}$ & 399 & 101 & 500 \\
\cline { 2 - 5 } & $\%$ & $79.8 \%$ & $20.2 \%$ & $100.0 \%$ & \\
\hline
\end{tabular}

Table no: 4 Distribution of the subjects as per Course studying and swelling at the front of the neck

\begin{tabular}{|c|c|c|c|c|c|}
\hline \multirow{2}{*}{\multicolumn{2}{|c|}{ Course }} & \multicolumn{2}{|c|}{$\begin{array}{c}\text { Swelling at the front of the } \\
\text { neck }\end{array}$} & \multirow[t]{2}{*}{ Total } & \multirow[t]{2}{*}{ P-Value } \\
\hline & & No & Yes & & \\
\hline \multirow{2}{*}{ Engineering } & $\mathrm{N}$ & 316 & 24 & 340 & \multirow[t]{8}{*}{0.234} \\
\hline & $\%$ & $92.9 \%$ & $7.1 \%$ & $100.0 \%$ & \\
\hline \multirow[t]{2}{*}{ Nursing } & $\mathrm{N}$ & 60 & 1 & 61 & \\
\hline & $\%$ & $98.4 \%$ & $1.6 \%$ & $100.0 \%$ & \\
\hline \multirow[t]{2}{*}{ Pharmacy } & $\mathrm{N}$ & 91 & 8 & 99 & \\
\hline & $\%$ & $91.9 \%$ & $8.1 \%$ & $100.0 \%$ & \\
\hline \multirow[t]{2}{*}{ Total } & $\mathrm{N}$ & 467 & 33 & 500 & \\
\hline & $\%$ & $93.4 \%$ & $6.6 \%$ & $100.0 \%$ & \\
\hline
\end{tabular}

Table no: 5 Distribution of the subjects as per the Course studying and Sensation of lump or hard mass in the throat

\begin{tabular}{|c|c|c|c|c|c|}
\hline \multirow{2}{*}{\multicolumn{2}{|c|}{ Course }} & \multicolumn{2}{|c|}{$\begin{array}{c}\text { Sensation of lump or } \\
\text { hard mass in the throat }\end{array}$} & \multirow[t]{2}{*}{ Total } & \multirow[t]{2}{*}{ P-Value } \\
\hline & & No & Yes & & \\
\hline \multirow{2}{*}{ Engineering } & $\mathrm{N}$ & 326 & 14 & 340 & \multirow[t]{8}{*}{0.554} \\
\hline & $\%$ & $95.9 \%$ & $4.1 \%$ & $100.0 \%$ & \\
\hline \multirow[t]{2}{*}{ Nursing } & $\mathrm{N}$ & 60 & 1 & 61 & \\
\hline & $\%$ & $98.4 \%$ & $1.6 \%$ & $100.0 \%$ & \\
\hline \multirow[t]{2}{*}{ Pharmacy } & $\mathrm{N}$ & 94 & 5 & 99 & \\
\hline & $\%$ & $94.9 \%$ & $5.1 \%$ & $100.0 \%$ & \\
\hline \multirow[t]{2}{*}{ Total } & $\mathrm{N}$ & 480 & 20 & 500 & \\
\hline & $\%$ & $96.0 \%$ & $4.0 \%$ & $100.0 \%$ & \\
\hline
\end{tabular}

Table no: 6 Distribution of the subjects as per the Age and Irregular periods

\begin{tabular}{|c|c|c|c|c|c|}
\hline \multicolumn{2}{|l|}{ Age } & \multicolumn{2}{|c|}{ Irregular periods } & \multirow{3}{*}{\begin{tabular}{c|} 
Total \\
367 \\
\end{tabular}} & \multirow{3}{*}{$\begin{array}{c}\text { P-Value } \\
0.801\end{array}$} \\
\hline & & \multirow{2}{*}{$\begin{array}{l}\text { No } \\
346 \\
\end{array}$} & \multirow{2}{*}{$\begin{array}{c}\text { Yes } \\
21 \\
\end{array}$} & & \\
\hline \multirow[t]{2}{*}{20 Years } & $\mathrm{N}$ & & & & \\
\hline & $\%$ & $94.3 \%$ & $5.7 \%$ & $100.0 \%$ & \\
\hline \multirow[t]{2}{*}{21 Years } & $\mathrm{N}$ & 78 & 9 & 87 & \\
\hline & $\%$ & $89.7 \%$ & $10.3 \%$ & $100.0 \%$ & \\
\hline \multirow[t]{2}{*}{22 Years } & $\mathrm{N}$ & 35 & 7 & 42 & \\
\hline & $\%$ & $83.3 \%$ & $16.7 \%$ & $100.0 \%$ & \\
\hline \multirow[t]{2}{*}{24 Years } & $\mathrm{N}$ & 3 & 1 & 4 & \\
\hline & $\%$ & $75.0 \%$ & $25.0 \%$ & $100.0 \%$ & \\
\hline \multirow[t]{2}{*}{ Total } & $\mathrm{N}$ & 462 & 38 & 500 & \\
\hline & $\%$ & $92.4 \%$ & $7.6 \%$ & $100.0 \%$ & \\
\hline
\end{tabular}

Table no: 7 Distribution of the subjects as per sex and Prevalence of thyroid disorders

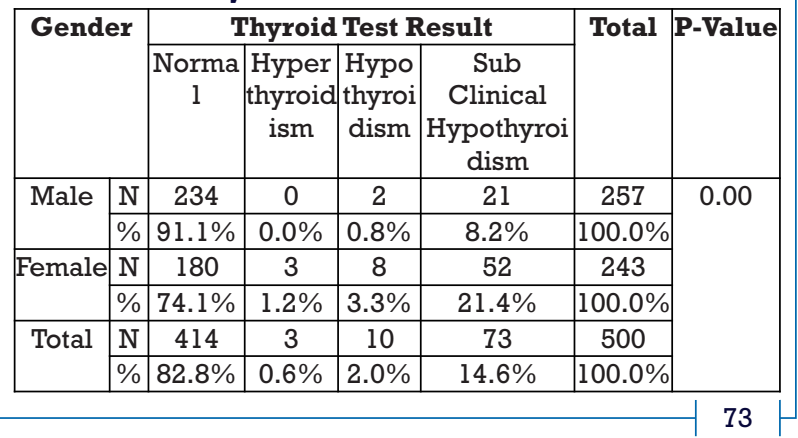




\section{DISCUSSION}

Two thirds (340) of the subjects $(n=500)$ are studying engineering. The male and female ratio of the sample is almost equal (51.4\%males/ $48.6 \%$ ). The majority of the subjects know about the thyroid gland and its functions through their teachers during their primary education. There's no difference between male and female subjects in their academic performance (above average 70\%). A higher percentage $(68 \%)$ of the subjects are taking Non- vegetarian diet occasionally ( weekly once). The maximum number $(94.8 \%)$ of subjects are consuming iodized salt.1.6 percent of the subjects are already having a history of thyroid disorders. Almost all of them are on medication ( 7 members out of 8 ) and $12.2 \%$ are suffering from other health issues. 20.2 percent of subjects are having a family history of thyroid disorders, mothers are having a higher prevalence $(90 \%)$. Unusual hair loss (45.6\%) and dryness of the hair (37.4\%) are the common symptoms that the majority of the subjects are having. Around 20 percent of subjects are complaining of other symptoms like dry skin, easy fatigue, excessive need for sleep, poor concentration, memory loss, and depression. 16 percent of the subjects are complaining of difficulty in tolerating cold. 4 percent of the subjects are having the sensation of the lump or hard mass in the throat and swelling at front of the neck. Irregular periods are the common symptom among female young adults $(7.6 \%)$. The majority of the subjects are complaining of symptoms of hypothyroidism. Biochemical analysis is indicating the Prevalence of Hypothyroidism 02 percent, Subclinical Hypothyroidism 14.6 percent and $0.6 \%$ Hyperthyroidism. Prevalence of subclinical hypothyroidism is among all thyroid disorders. The prevalence of thyroid disorders, as well as subclinical hypothyroidism, is high among $(75 \%)$ females than males. As per these findings, female young adults need to be given more attention for screening and management of subclinical hypothyroidism as early as possible to prevent the prevalence of overt Hypothyroidism. At the same time to reproduce healthy new offspring, Hypothyroidism can show an impact on reproductive health.

\section{REFERENCES:}

1. Brahmbhatt SR, Brahmbhatt RM, Boyages SC. Impact of protein energy malnutrition on thyroid size in an iodine deficient population of Gujarat (India): Is it an aetiological factor for goitre J Endocrinol. 2001;145:11-7. [PubMed]

2. Brahmbhatt SR, Fearnley R, Brahmbhatt RM, Eastman CJ, Boyages SC. Study of biochemical prevalence indicators for the assessment of iodine deficiency disorders in adults at field conditions in Gujarat (India) Asia Pac J Clin Nutr. disorders in adults at field

3. Brahmbhatt SR, Brahmbhatt RM, Eastman CJ, Boyages SC. Thyroid ultrasonography consistently identifies goitre in adults over the age of 30 years despite a diminished response with aging of the thyroid gland to the effects of goitrogenic. Scientific World Journal. 2001;1:243-53. [PMC free article] [PubMed]

4. Chakraborty I, Mazumdar P, Chakraborty PS, Chattopadhyay G, Bhowmick K. Iodine deficiency disorder among pregnant women in a tertiary care hospital of Kolkata, India. Southeast Asian J Trop Med Public Health. 2010;41:989-95. [PubMed]

5. Desai PM. Disorders of the Thyroid Gland in India. Indian J Pediatr. 1997;64:11-20. [PubMed]

6. Gangadharan P, Nair MK, Pradeep VM. Thyroid Cancer in Kerala. In: Shah AH, Samuel AM, Rao RS, editors. Thyroid Cancer- An Indian Perspective. Mumbai: Quest Publications; 1999.pp. 17-32/.

7. Karmarkar MG, Deo MG, Koch Pillai N, Ramalingaswami V.Pathophysiology of Himalayan endemic goitre. Am J Clin Nutr. 1974;27:96-103. [PubMed]

8. Marwaha RK, Chopra S, Gopalakrishnan S, Sharma B, Kanwar RS, Sastry A, Singh S. Establishment of reference range for thyroid hormones in normal pregnant Indian women. BJOG. 2008;115:602-6. [PubMed]

9. Marwaha RK, Tandon N, Ashraf GM, Ganguly SK, Batra A, Aggarwal R, et al. Ultrasound evaluation of thyroid size: $A$ large nationwide study of schoolchildren in India. Natl Med India. 2008;21:69-74. [PubMed]

10. Marwaha RK, Tandon N, Desai AK, Kanwar R, Aggarwal R, Sastry A, et al. Reference range of thyroid hormones in healthy school-age children: Country-wide data from India. Clin Biochem. 2010;43:51-6. [PubMed]

11. Marwaha RK, Tandon N, Desai A, Kanwar R, Grewal K, Aggarwal R, et al. Reference range of thyroid hormones in normal Indian school-age children. Clin Endocrinol (Oxf) 2008;68:369-74. [PubMed]

12. Marwaha RK, Tandon N, Gupta N, Karak AK, Verma K, Kochupillai N. Residual goitre in the post ionization phase: Iodine status, thiocyanate exposure and autoimmunity. Clin Endocrinol (Oxf) 2003;59:672-81. [PubMed] 13. Marwaha RK,Tandon N, Karak AK, Gupta N,Verma K, Kochupillai N.

13. Hashimoto's thyroiditis: countrywide screening of goitrous healthy young girls in post iodization phase in India. J Clin Endocrinol Metab. 2000;85:3798-802. [PubMed]

14. Pandav CS, Karmarkar MG, Kochupillai N. Recommended levels of salt iodization in India. Indian J Pediatr. 1984;51:53-4. [PubMed]
15. Rao DN. Thyroid Cancer- An Indian Perspective. In: Shah AH, Samuel AM, Rao RS, editors. Thyroid Cancer- An Indian Perspective. Mumbai: Quest 1999.pp.3-16.

16. Deo MG, Karmarkar MG, Kochupillai N, Ramachandran K, Ramalingaswami V. Prevention of endemic goitre with iodized salt. 1973. Natl Med J India. 2001; 14:185-8. [PubMed]

17. Usha Menon V,Sundaram KR, Unnikrishnan AG,Jayakumar RV,NairV, Ku mar H. High prevalence of undetected thyroid disorders in an iodine sufficient adult south Indian population.J Indian Med Assoc. 2009;107:72-7. [PubMed] 